\title{
LOOKING INSIDE VOTIVE CREATURES: \\ COMPUTED TOMOGRAPHY (CT) SCANNING OF ANCIENT EGYPTIAN MUMMIFIED ANIMALS IN IZIKO MUSEUMS OF SOUTH AFRICA: A PRELIMINARY REPORT ${ }^{1}$
}

\author{
I Cornelius (Stellenbosch University), L C Swanepoel (Stellenbosch University),
} A du Plessis (Stellenbosch University), R Slabbert (Stellenbosch University)

The ancient Egyptians mummified many more animals than humans. The study of ancient Egyptian animal mummies is varied and extensive. Currently new methodologies and modern technology are being used to unlock the secrets of animal mummies. Recently five animal mummies housed in the Egyptian collection of Iziko Museums of South Africa in Cape Town were scanned using a state of the art computed tomography (CT) scanner at Stellenbosch University. Preliminary results revealed two complete bird skeletons, a claw, a fake and the partial skeleton of what appears to be a cat.

The aim of this article is to inform on the scanning of ancient Egyptian animal mummies in Iziko Museums of Cape Town. It looks at the types of animal mummies, describes the way in which animal mummies are studied, the project itself, the Stellenbosch CT scanner, and gives some preliminary results.

\section{Animal mummies in ancient Egypt}

The ancient Egyptians believed in life after death and mummified their dead to preserve the body for 'eternity'. ${ }^{2}$ They not only mummified humans, they also mummified a great variety of animals. As a matter of fact, they mummified many more animals than humans. Mummified animals comprise four types: pet mummies, food mummies, sacred animals and votive mummies. ${ }^{3}$

(i) Pet mummies. Pets such as cats and dogs accompanied their owners into the afterlife. Mummified animals are found in tombs or nearby, some buried in their own coffins. A dog was found in the Valley of the Kings and might have been a royal pet (Ikram 2005a:Fig. 1.2). A baby

1 The kind cooperation of Iziko Museums of South Africa (Cape Town) is acknowledged: Lalou Meltzer, Esther Esmyol, Bradley Mottie, Janene van Wyk and Carina Beyer (photographs). A word of thanks is also expressed to Anlen Boshoff who has been part of this project since its inception.

2 On mummification in Egypt in general see inter alia Ikram \& Dodson 1998; Aufderheide 2003; Dunand \& Lichtenberg 2006; Ikram 2010 and Taylor 2010.

3 For animal mummies in general see Ikram 2005. 
baboon was buried with queen Makatra, earlier thought to be a human (Partridge 1994:195-197, Figs. 171, 174). Hapymin was found with his dog curled up at his feet. ${ }^{4}$ Another case is a pet gazelle from Deir el-Bahari (Ikram 2000:59).

(ii) Food mummies. Mummified animals or parts of animals served as food for the dead. Meat was dried as ancient Egyptian 'biltong' (Ikram 1995). Animals were specially prepared - there are, for example, joints of meat like a foreleg of a calf or whole birds like geese, which were wrapped and placed in special shaped coffins and were even given a 'roasted browning'. In the famous tomb of TutankhAmen there were 25 coffinettes containing food mummies. ${ }^{5}$

(iii) Sacred animals. This is the most famous group of animal mummies. There was the cult of the Apis bull (Dodson 2005) and the ram of Mendes (Redford 2010). The animal was mummified after death and ritually buried. ${ }^{6}$

(iv) Votives. These can be classified as votive offerings to specific deities: the cat to Bastet, the ibis to Thoth and the falcon to Horus. ${ }^{7}$ Votive mummies of animals were especially popular in the Graeco-Roman period after $300 \mathrm{BC}$ and ending with the advent of Christianity during the $4^{\text {th }}$ century AD. Mummies were donated by pilgrims and ritually buried in special containers in niches in catacombs attached to temples. This is the largest number of mummified animals, of which there are millions; there are estimates of four million for Tuna el-Gebel Hermopolis and new discoveries at Saqqara estimate eight million dog mummies (El-Aref 2013). These mummies served as a sort of 'prayer' to a certain deity, like lighting a candle in a church (Ikram 2005a:9). A plea to a god like Thoth might have been written on linen and wrapped around the mummified animals (Ray 2005:177-178). ${ }^{8}$

4 Found by Petrie at Abydos (1902) and now in Philadelphia (E16220a and 16219).

5 Cf. http://www.griffith.ox.ac.uk/perl/gi-ca-qmakedeta.pl?sid=41.164.7.165-13547361 $08 \& q n o=1 \&$ dfnam $=062$ b-c062-6.

6 According to some classical authors the Egyptians worshipped animals (Smelik \& Hemelrijk 1984 and Feder in Fitzenreiter 2003). Although animals were very important in ancient Egypt (cf. Boessneck 1988; Arnold 1995 and Germond 2001) and of religious significance (te Velde 1980; Fitzenreiter 2003 and Dodson 2009), the Egyptians did not exactly 'worship' animals - they only believed that the animal was a manifestation of the deity's power, its hypostasis, its avatar (Ikram 2005a:10). Not every dog or cat was regarded as a god or goddess, but it first had to be consecrated.

7 For a list of different animal species and cemeteries cf. Ikram 2005:xviii-xx; map xvii.

8 According to Kessler 1989 the animals were not votive offerings as such, but any animal living and dying on temple land could be consecrated to a deity and buried. 


\section{The study of animal mummies}

The study of ancient Egyptian animal mummies goes back to the birth of Egyptology. Napoleon's expedition (Gillispie \& Dewachter 1987:Pls. 51, 53-55) brought back animal mummies and already in 1834 Pettigrew (169ff.) described animal mummies. The topic is currently receiving much scholarly attention. There is for example the very important animal mummy project of Salima Ikram, who is working on the mummies in the Cairo Museum. ${ }^{9}$ There is also the project of Kessler of the Ludwig Maximilians-Universität München, who is working at Tuna al-Gebel ${ }^{10}$ and at the University of Manchester there is the Ancient Egyptian Animal Bio Bank Project. ${ }^{11}$ On the Web there is the Animal Mummy Database. ${ }^{12}$ Many publications have appeared in recent years in Egyptological literature, more popular magazines like National Geographic (e.g. Williams 2009), but also in scientific journals (e.g. Kurushima et al 2012). The leading author on the subject of animal mummification is Ikram (e.g. 2005).

The study of Egyptian animal mummies involves various research questions:

- Where was the mummy found: the site (e.g. Saqqarah) and find spot (e.g. a tomb)?

- From which period does the mummy date?

- What does the mummy look like on the outside?

- What kind of animal is involved? A cat, a bird or some other creature? What species of bird: an ibis or a falcon, for example?

- How was the animal killed before it was mummified? Votive animals had to be intentionally killed. Was it strangled, knocked over the head, dipped into some substance or even poisoned?

- How was it mummified: what do we know about the process of mummification?

'Experimental Archaeology' can also help and Ikram for example has even experimented by mummifying rabbits (2005b:29ff.). How was the animal wrapped? Scholars now argue that in spite of the scale of production, mummification procedures were often as complex as those used for humans (e.g. Buckley et al 2004): evisceration, desiccation by using natron and elaborate

9 Ikram 2005c and www.animalmummies.com; cf. the two catalogues of the Cairo material by Gaillard \& Daressy 1905 and Ikram \& Iskander 2002.

10 Kessler 1989, 2003; Kessler \& Nur el-Din 2005 and http://tunaelgebel.wordpress.com.

11 www.knhcentre.manchester.ac.uk/research/animalbiobank/; David 2008.

12 www.animalmummies.net. 
bandaging. The wrapping helps in dating the mummy - for example elaborate patterns are typical of mummies from the Roman period. ${ }^{13}$

In order to answer these questions there are new methodologies and techniques which involve contemporary high-tech equipment to x-ray and scan the mummies (Aufderheide 2003; Jackowski 2007 and Lynnerup 2009). The scanning of human mummies by way of x-ray is well-known and already goes back to 1896 and the pioneer Sir Flinders Petrie in 1898 (Ikram \& Dodson 1998:95). Scanning animal mummies (cf. McKnight 2010) enables one to look 'inside' the animal mummy without unwrapping or risking damaging it. By x-raying / scanning animal mummies some of the questions raised above can be answered. One aspect that such work has revealed is that many mummies are 'dummy mummies' as Bob Brier (2001) described them - fakes, containing only rags, twigs or plant material, mud, pottery, or only some odd bones or part of an animal. What one sees at first glance on the outside is not necessarily what is inside. For example one mummy is decorated with a falcon Horus appliqué, but inside is an ibis (Ikram 2005b:Pl. 3.1), a hawk wrapped in an intricate herringbone pattern contains only a twig or bone fragment (Ikram 2005b:Pl. 1.5) and what resembles an ibis mummy only contains sand and mud (Ikram 2005c:Fig. 9.11). One can explain the lack of a complete animal body in various ways. It is possible that the animal was difficult to catch or to breed, as in the case of falcons. Another reason might be commercialisation and mass consumption or over-exploitation: fakes were made or only parts of the animal were mummified as the cheaper option for poor pilgrims or due to the scarcity of raw materials and live resources. Perhaps the outward form or only part of an animal was sufficient and served the cause: pars pro toto.

Interesting results can also be obtained through the study of complete animal remains. The bones 'speak' to us in various ways; they give us information:

- about the process of mummification,

- tell us what kind of animal is inside (e.g. a cat),

- and may even show how it was killed (e.g. when the head is detached) (Armitage \& Clutton-Brock 1981:189; Jackowski et al 2008:1488).

The study of ancient Egyptian animal mummies informs us on:

(i) The animal world of the ancient Egyptians, i.e. which species are involved.

(ii) The relationship between the ancient Egyptians and their animals, i.e. that they loved cats.

(iii) The role of animals in ancient Egyptian cult and religion.

13 E.g. Ikram 2005a:Pl. 1.5. 
3. The project: The animal mummies of Iziko Museums of South Africa in Cape Town

The Egyptian collection of artefacts in Iziko Museums of South Africa in Cape Town includes five animal mummies: four birds $(1597,1718 \mathrm{a}-\mathrm{b}, 2575)$ and what might be a cat (1650). ${ }^{14}$ These animals are presumably of the votive mummy type. There is great uncertainty about the exact origin of these mummies and this is yet to be properly investigated. According to the Iziko catalogue cards, two of the mummies (1718a-b) are from Kafr Ammar, the later cemeteries at Tarkhan $50 \mathrm{~km}$ south of Cairo, excavated by Petrie (1915). One bird (1597) is said to come from Thebes.

The phases of the project are the following:

- Preliminary visual examination of the material in Cape Town: done on $5^{\text {th }}$ June 2012.

- Scanning: three birds (1718a-b, 2575) and the 'cat' (1650) were scanned at the Central Analytical Facilities, Stellenbosch University (see under 4 ) on $28^{\text {th }}$ June. These were scanned again on $11^{\text {th }}$ October together with a fourth bird (1597).

- Technical analysis of the scanned material (see under 5).

- Analysis of some of the substances found with the 'cat' and one of the birds (see under 5).

- Future aspects include scientific analysis of the wrapping material, radiocarbon dating (which can not be done in South Africa) and the involvement of experts like the renowned Salima Ikram.

\section{The CT scanner of Stellenbosch University}

The Stellenbosch Computed Tomography (CT) Scanner facility, forming part of the Stellenbosch University's Central Analytical Facilities, was launched in April 2012. The instrument is a microfocus X-ray CT scanner model General Electric Phoenix V|Tome|X L240 with additional NF180 option. Any object can be scanned using $\mathrm{x}$-rays to visualize the internal structure in $3 \mathrm{D}$ or to make accurate measurements or more advanced analyses of materials. ${ }^{15}$

The sample, in this case the mummified object, is placed on a rotating stage. $\mathrm{X}$-ray projection images (normal x-ray images) are acquired at up to 3000 angles around the object as it rotates slowly. After scanning, these images are then

\footnotetext{
14 On other objects in this collection which were exhibited in Stellenbosch, cf. inter alia Cornelius 2005. For a list of mummies in other museums cf. El Mahdy 1991:177-180.

15 For more information visit the website blogs.sun.ac.za/ctscanner.
} 
reconstructed to provide full $3 \mathrm{D}$ data. This data can then be manipulated using volume imaging software. A 3D image with thresholding allows one to view images of specific components such as the insides of the mummies in three dimensions, with high contrast. This allows the virtual unwrapping of the mummies to reveal their secrets.

\section{Preliminary results}

\section{$5.1 \quad$ Iziko $1718 \mathrm{a}$}

Iziko 1718a (Fig. 1) ${ }^{16}$ is similar in shape to other published images of ibis mummies (Nicholson 2005:Fig. 3.3; cf. Ikram \& Iskander 2002:94). There are no decorations on the exterior wrappings. A black substance, most likely some oxidised organic material or resin, is found along the edges where the wrappings are glued in place. The bottom section of the mummy is damaged and plant material is protruding from this section.

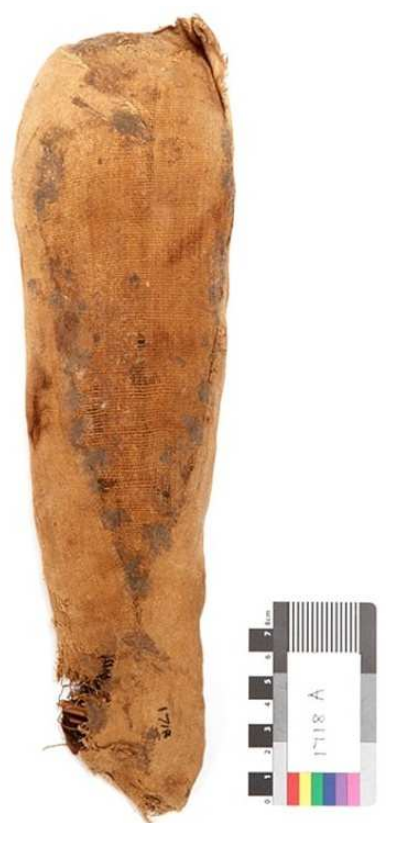

Fig. 1: Photograph of Iziko 1718 a shows the shape of an ibis. A black 'glue' can be seen where the wrappings are joined and the damaged section at the bottom shows protruding plant material.

(C) Iziko Museums + Photograph Carina Beyer

16 More photographs are available at http://blogs.sun.ac.za/as/2012/08/16/looking-insideancient-egyptian-animal-mummiesn-kykie-binne-antieke-egiptiese-dieremummies/. 
The CT-scan of Iziko 1718a showed that no animal remains are present (Figs. $2 A$ $\& B$ ). The wrappings contain plant material, possibly papyrus reeds with mud and linen stuffed in for extra support and shaping $(2 B)$. The mud and extra linen were used to create the wider top section of the mummy to give it an ibis shape. The reeds give the mummy rigidity. The scanning also shows that at least five layers of linen were used for the wrapping $(2 B)$, but whether the linen is a single unit or separate pieces still needs to be confirmed. Denser objects can also be identified and are visualised as white in this scan. These objects are most likely small stones present within the mud used for the stuffing.
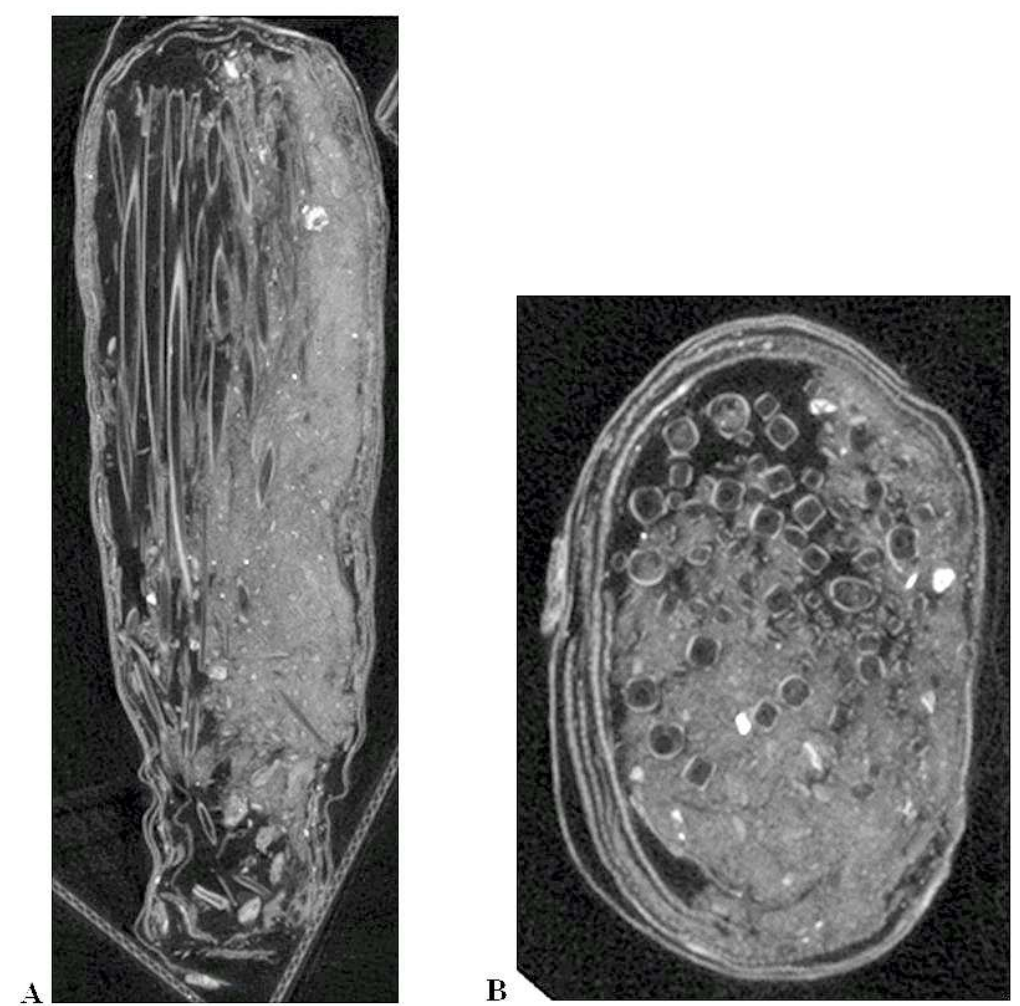

Figs. $2 A$ and B: X-ray images of a cross-section (A) and a top-section (B) of Iziko 1718 a showing that no animal remains are present, but only plant material, mud and linen.

() Stellenbosch University 


\section{$5.2 \quad$ Iziko $1718 b$}

Iziko 1718 b is shaped like a falcon (Fig. 3; cf. Dunand \& Lichtenberg 2006:121). A head and body are clearly discernible. A beak-like structure is also seen on the head. Different weave patterns and types of linen were used in the construction of the mummy. The same black substance as on Iziko 1718a is found where the linen pieces are attached to each other. Stitching at the seams is visible at the back of the mummy (not shown). Additional support is found around the neck area to hold the head in place. Few markings are found on the exterior, but the black spots on the head area quite possibly represent eyes.

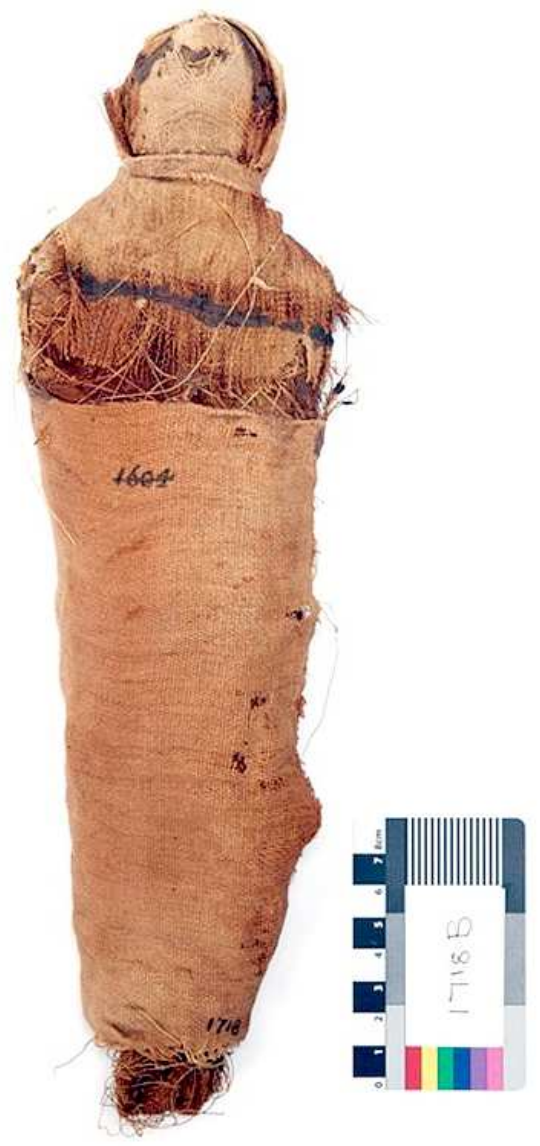

Fig. 3: A photograph of Iziko $1718 b$ shows that it is in the shape of a bird of prey. The head area has a beak structure and two markings which possibly represent eyes. Extra linen around the neck area supports the head. Note the different linen types and patterns.

(C) Iziko Museums + Photograph Carina Beyer 
The CT-scan of Iziko $1718 \mathrm{~b}$ showed the remains of the leg and talons of a bird of prey (Fig. 4). The remains are surrounded by a number of objects that could be plant material such as papyrus reeds or feathers (Fig. 5). This bundle of organic material is tightly wrapped in multiple layers of linen for support and shaping.

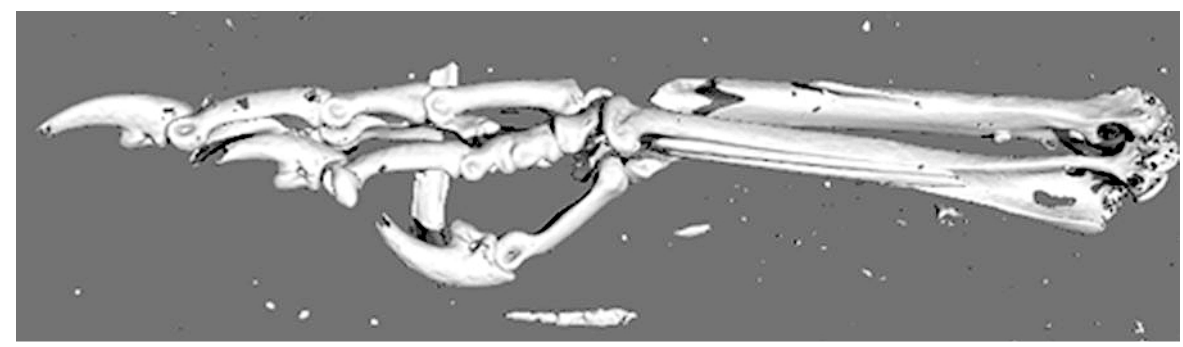

Fig. 4: A CT-scan rendering of the bird of prey leg found within Iziko $1718 b$. (c) Stellenbosch University

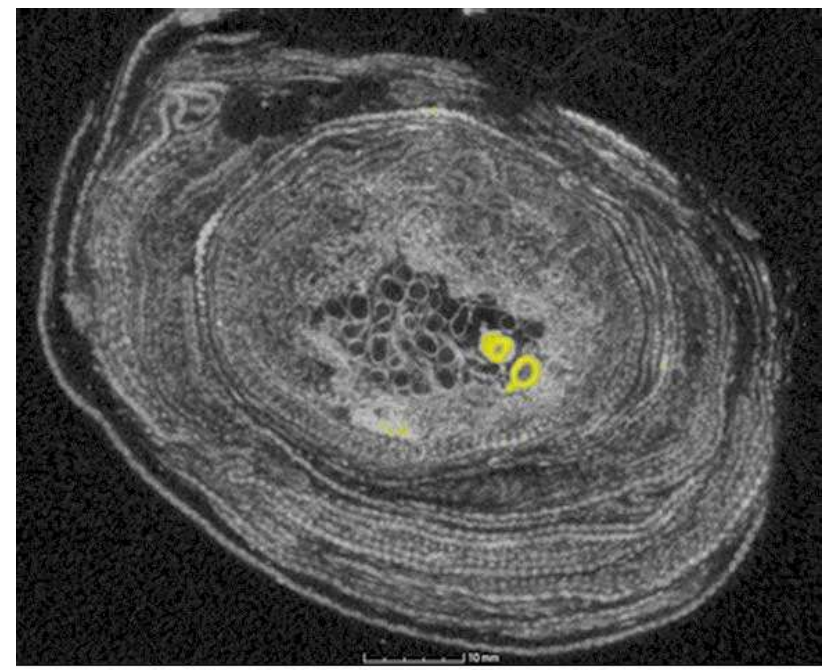

Fig. 5: A top-section of the $x$-ray image of Iziko $1718 b$ shows the position of the bird of prey leg (yellow) surrounded by either reeds or feathers. Multiple layers of linen were used for the construction of this mummy.

(c) Stellenbosch University 


\subsection{Iziko 1650}

Iziko 1650 is damaged and worn. The shape would suggest that it contains a mammal, possibly a cat (Fig. 6). ${ }^{17}$ The top is formed in the shape of a head, with tightly bound linen protrusions for ears. The wrapping extends into a nose area from the ears. A number of black dots are seen on the head area around the ears.

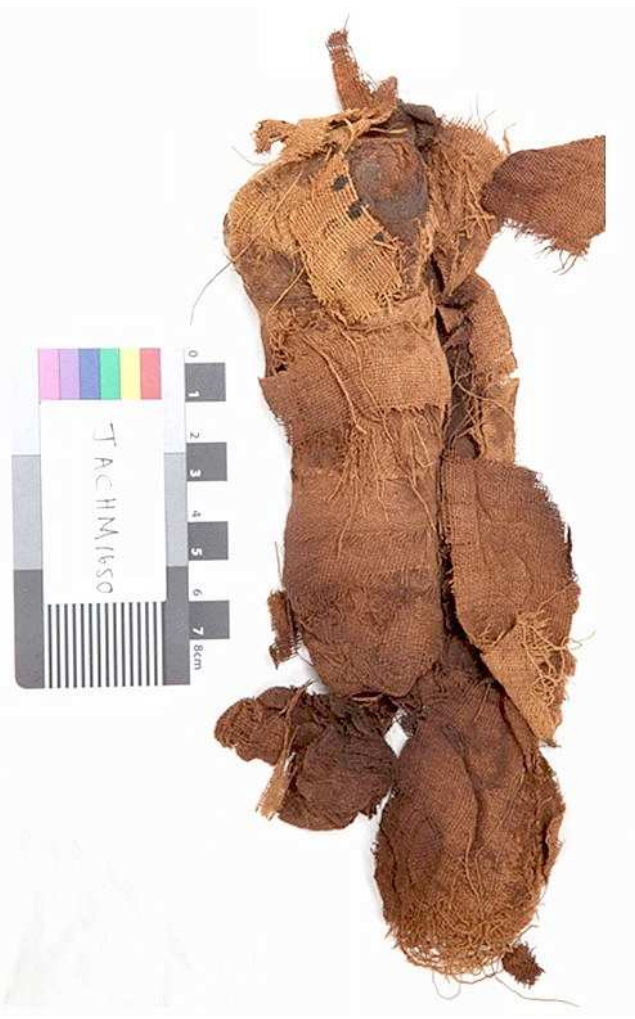

Fig. 6: Iziko 1650 shows a head area at the top with ears (top centre). The shape indicates that it represents a mammal, possibly a cat. Black dots can be seen surrounding the area around the ears.

(c) Iziko Museums + Photograph Carina Beyer

17 Cf. Ikram \& Iskander 2002:71ff. and Málek 1993:123ff. 
The inside of Iziko 1650 contains the remains of a mammal (Fig. 7). The head, front legs and some vertebrae are missing, making definite identification of the species difficult. The number of vertebrae still present suggests that the remains may belong to a cat (Felis spp.). The size (as measured by the calliper function of the volume imaging software) of the skeleton tells us that it may be a kitten. Young cats $(<12$ months old) have been found in other studies (Armitage \& Clutton-Brock 1981; Gnudi et al 2012). The skeleton shows some damage. The chest area is crushed and a few bones are broken. The damage could have been caused during the mummification process or by the brittleness of the bones or through some careless handling. The damage could also have been sustained in the centuries following the mummification and burial of the cat. The latter is more likely considering the general condition of the mummy today, but the chest areas of young cats have been known to collapse due to the pressure of the binding (Armitage \& Clutton-Brock 1981). The scan shows very dense material within and around the chest area (Fig. 8). The material still needs to be identified, but it may be either clay or rock (natron). Natron is a natural mixture of salts found in rock form in Egypt and was used to remove water and bodily fluids during the mummification process (Ikram 2005b:17 and Lucas \& Harris 1962:278ff., 302-303).

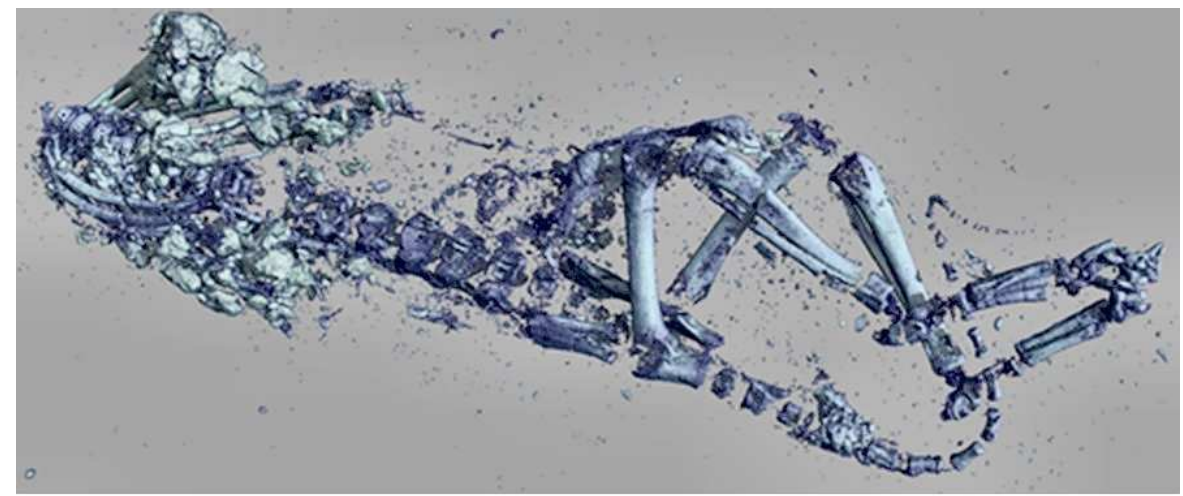

Fig. 7: A CT-scan rendering of the skeletal remains within Iziko 1650. The skeleton belongs to a mammal, most likely a very young kitten. The remains have been damaged either during the mummification process or by physical trauma during subsequent centuries.

(c) Stellenbosch University 


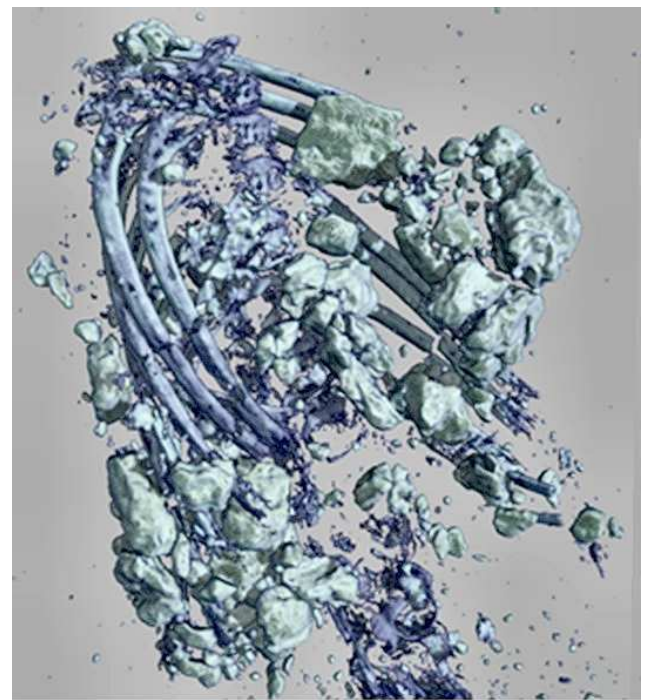

Fig. 8: A CT-scan rendering of the highly dense material found in and around the chest area of the mummy. The material can be rock (such as natron) or clay.

(C) Stellenbosch University

\section{$5.4 \quad$ Iziko 2575}

Iziko 2575 is a falcon (Fig. 9). The linen used for the wrapping has blackened, most likely due to oxidation of plant oils used during the mummification process. Alternatively, the wrappings could have been covered in a substance generally referred to as resin. Some damage is visible at the head, claws and right wing area. As a result the eyes, beak and feather shafts are clearly visible.

The CT-scan of Iziko 2575 shows that the complete skeleton of a bird of prey is present (Fig. 10). No broken bones or vertebrae were observed, indicating that the bird was not killed by any physical trauma. The major bones were measured using the calliper function of the volume imaging software for preliminary species identification. These measurements suggest that this is an adult falcon and likely a common kestrel (Falco tinninculus).$^{18}$ This species is ubiquitous in the Mediterranean region and was also identified in other radiological studies as one of the species being mummified (Morgan et al 2011).

18 Cf. Houlihan 1986:45 for birds in Egypt and now Bailleul-LeSuer 2012. 

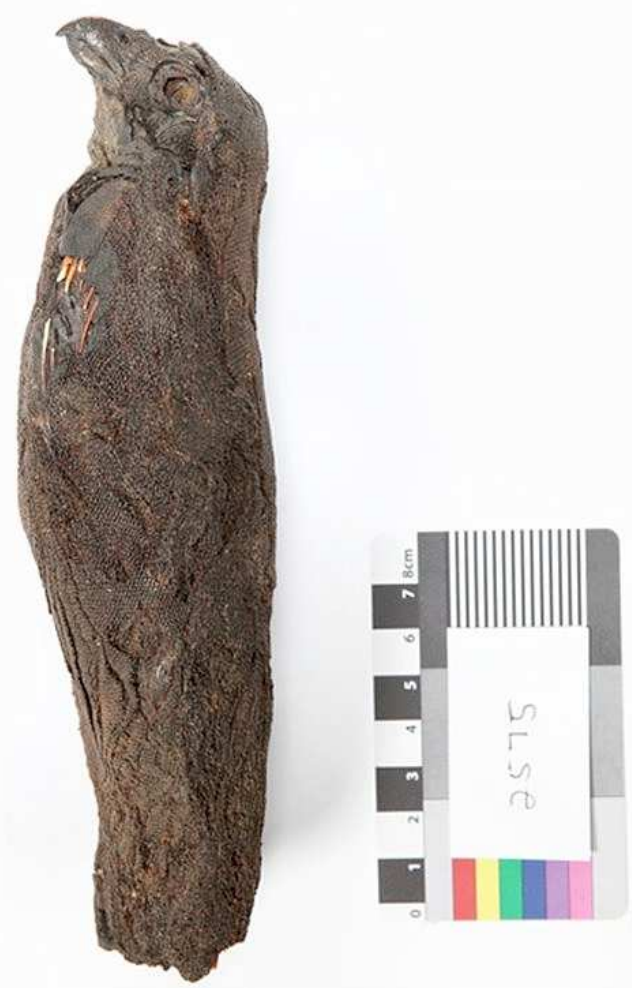

Fig. 9: A photograph of Iziko 2575 clearly shows a mummified bird of prey.

The eyes and beak and some feather shafts are visible (top left).

(C) Iziko Museums + Photograph Carina Beyer

An interesting observation was the presence of the falcon's last meal consisting of small, denser bone fragments. The presence of these smaller bones is expected, because the diet of these small falcons consists of rodents and insects (Schmidt et al 2002). The small bones were observed within the area where the gizzard can be found in living birds. It is not yet established whether the gizzard was removed and replaced during the evisceration process, such as was seen with some ibises (Wade et al 2012). The presence of the food in the gizzard is a good indicator of time of death. The gizzard in birds of prey is usually emptied by the following morning after ingesting food (Bond 1936:75). This bird died on the same day that it ate. 


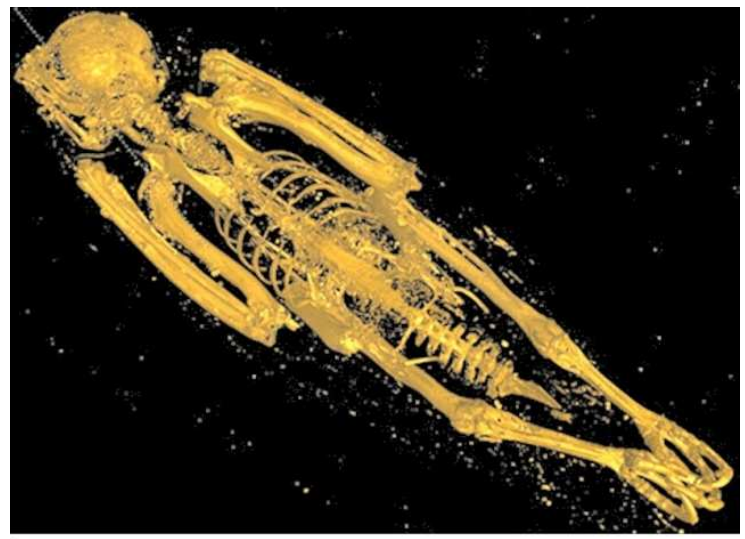

Fig. 10: A CT-rendering of Iziko 2575 shows the intact skeleton of a mummified bird of prey. (C) Stellenbosch University

\subsection{Iziko 1597}

Iziko 1597 has a bird shape (Fig. 11 opposite page). No damage or markings can be observed. Some discolouration of the linen can be seen, also due to oxidation of plant oils.

The inside of Iziko 1597 contains the complete skeleton of a bird of prey (Fig. 12). Preliminary species identification is yet to be performed. No damage to the bones and vertebrae can be observed, suggesting that this bird was not killed by physical trauma. The wing and tail feathers are preserved and can be observed in the scan.

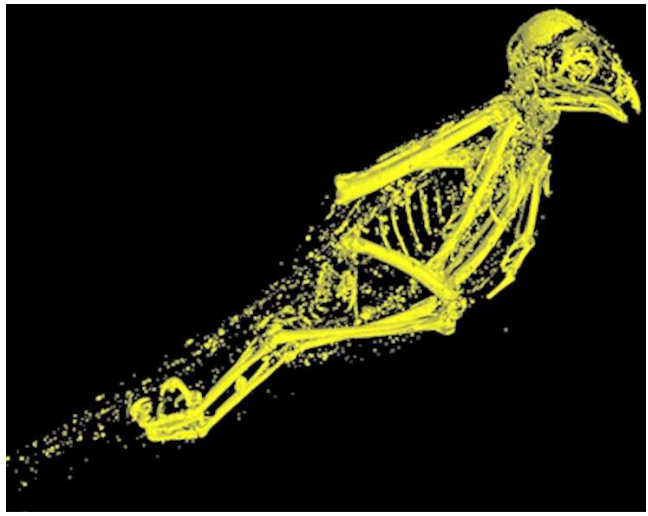

Fig. 12: A CT-scan rendering of the complete bird of prey skeleton found within Iziko 1597. The intact wing and tail feathers are visible bottom left.

(C) Stellenbosch University 


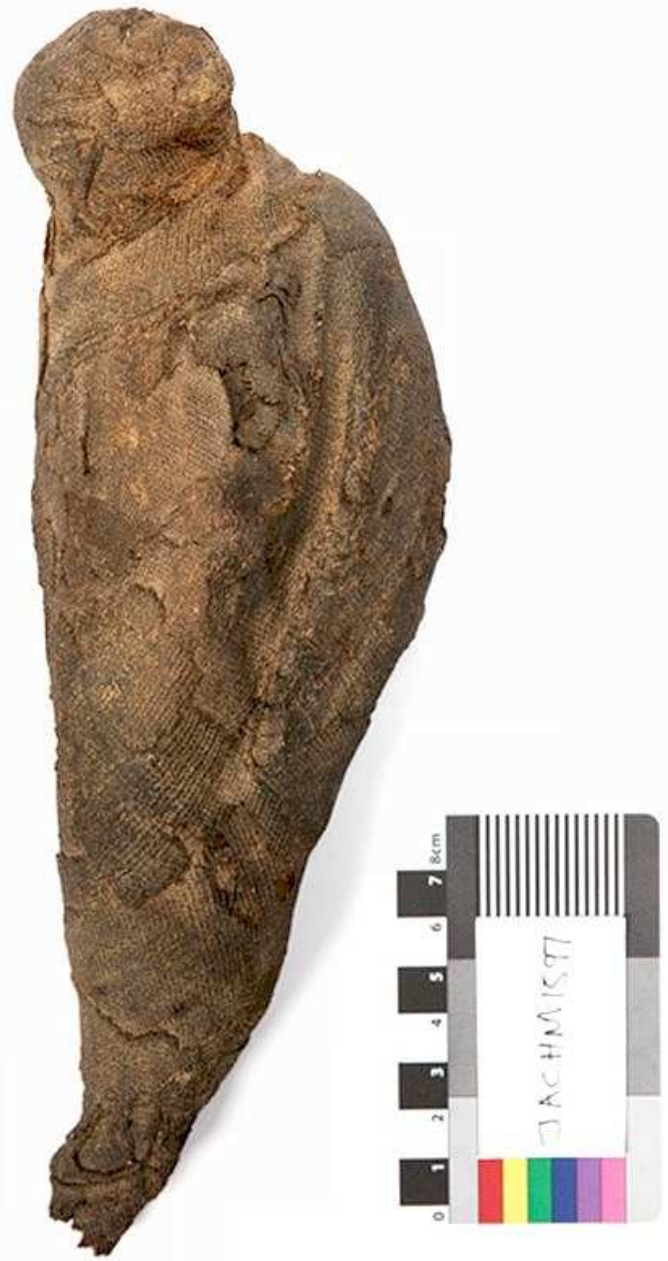

Fig. 11: A photograph of Iziko 1597 shows a bird-shaped mummy. (C) Iziko Museums + Photograph Carina Beyer 


\subsection{Preliminary chemical analyses}

A number of different compounds are used in the mummification process. The most common compounds found were unsaturated plant oils and animal fats, which stabilise tissues and textiles and inhibit microbe activity (Buckley \& Evershed 2001:839-840).

Linen from Iziko 1650 and 2575 were analysed using gas chromatography-mass spectrometry at the Central Analytical Facilities, Stellenbosch University. The most abundant substances found on the linen of Iziko 1650 were plant oils such as palm oils. Iziko 2575 contained a number of substances. These include plant oils such as palm oil and a number of resin acid residues, which would explain the colour of this specific mummy.

\section{Summary and conclusions}

The scanning of the five mummified animals in the Cape Town collection revealed that the one bird-shaped (1718a) object was a complete fake, containing only plant material, mud, linen and perhaps small stones. The second bird looks like a falcon on the outside with the weave pattern and clear stitching, but the scan revealed that it only contained a leg and talons surrounded by reeds or feathers and linen (1718b). One animal has no clear shape. ${ }^{19}$ The scan showed that the head, front legs and vertebrae are missing, but it could be a small kitten (1650). It might also contain clay or rock natron. The two other items are complete birds (2575 and 1597). The first one is possibly a kestrel falcon. The eyes, beak and some feathers are clearly visible. The wrapping has blackened, maybe due to oils or resin. The scan shows no broken bones, but the presence of the 'last meal' is an interesting find. The second bird of prey also shows some discolouration and the wing and tail feathers. The scan showed no damage to the bones.

The preliminary chemical analysis showed the presence of previously reported substances used in mummification, including oils and resins.

More in-depth analyses are required to get a better picture of:

(i) the substances found in the mummies

(ii) the patterns of the wrappings

(iii) the way in which the two complete birds were killed

19 Izak Cornelius called it 'the thing'. 
(iv) the mummification process involved ${ }^{20}$

(v) an approximate date for the mummification, using radiocarbon dating (which can only be done overseas).

The project in its initial phase has provided interesting results but also poses several questions which future in-depth research hopes to answer.

\section{BIBLIOGRAPHY}

Armitage, P L \& Clutton-Brock, J 1981. A radiological and histological investigation into the mummification of cats from ancient Egypt. Journal of Archaeological Science 8:185-196.

Arnold, D 1995. An Egyptian bestiary. The Metropolitan Museum of Art Bulletin, New Series, 52.4:1-64.

Aufderheide, A C 2003. The scientific study of mummies. Cambridge: Cambridge University Press.

Bailleul-LeSuer, R 2012. Between heaven and earth: Birds in ancient Egypt. Oriental Institute Museum Publications 35. Chicago: The Oriental Institute of the University of Chicago.

Boessneck, J 1988. Die Tierwelt des Alten Ägypten. München: C H Beck.

Bond R M 1936. Eating habits of falcons with special reference to pellet analysis. The condor 38:72-76.

Brier, B 2001. Case of the dummy mummy. Archaeology 54.5:28.

Buckley S A \& Evershed R P 2001. Organic chemistry of embalming agents in Pharaonic and Graeco-Roman mummies. Nature 413:837-841.

Buckley, S A et al 2004. Complex organic chemical balms of Pharaonic animal mummies. Nature 431:294-299.

Cornelius, I 2005. Van die Nyl tot Stellenbosch: Antieke Egiptiese voorwerpe in Stellenbosch. Akroterion 50:125-136.

David, R (ed.) 2008. Egyptian mummies and modern science. Cambridge: Cambridge University Press.

Dodson, A 2005. Bull cults. In Ikram, S (ed.), Divine creatures: Animal mummies in ancient Egypt, 72-105. Cairo / New York: The American University in Cairo Press.

Dodson, A 2009. Rituals related to animal cults. In Dieleman, J \& Wendrich, W (eds.), UCLA Encyclopedia of Egyptology, Los Angeles. http://escholarship.org/uc/item/6wk541n0. Accessed 17 December 2012.

20 During 2013 Ikram will visit South Africa and form part of the team studying the mummies. Part of this project is the study of animal mummies in other South African collections. 
Dunand, F \& Lichtenberg, R 2006. Mummies and death in Egypt. Ithaca, NY: Cornell University Press.

El-Aref, N 2013. Eight million dog mummies found in Saqqara. Ahram Online. http://english.ahram.org.eg/News/61381.aspx. Accessed 3 January 2013.

El Mahdy, C 1991. Mummies, myth and magic in ancient Egypt. New York: Thames \& Hudson.

Gaillard, C \& Daressy, G 1905. Catalogue Général des Antiquités Égyptiennes du Musée du Caire: La Faune Momifiée de l'Antique Égypte. Cairo: IFAO.

Germond, P 2001. Das Tier im alten Ägypten. München: Hirmer.

Gillispie, C C \& Dewachter, M 1987. The monuments of Egypt: The Napoleonic edition. New York: Princeton Architectural Press.

Gnudi, G et al 2012. Radiological investigation of an over 2000-year-old Egyptian mummy of a cat. Journal of Feline Medicine and Surgery 14:292-294.

Feder, F 2003. Der ägyptische Tierkult nach den griechischen und römischen Autoren. In Fitzenreiter, M (ed.), Tierkulte im pharaonischen Ägypten und im Kulturvergleich, IBAES IV, 159-166. Berlin: Humboldt-Universität. http://www2.hu-berlin.de/nilus/net-publications/ibaes4/publikation/ tierkulte.pdf. Accessed 17 December 2012.

Fitzenreiter, M (ed.) 2003. Tierkulte im pharaonischen Ägypten und im Kulturvergleich, IBAES IV. Berlin.

http://www2.rz.hu-berlin.de/nilus/net-publications/ibaes4. Accessed 17 December 2012.

Houlihan, P F 1986. The birds of ancient Egypt. Cairo: The American University in Cairo Press.

Ikram, S 1995. Did the ancient Egyptians eat biltong? Cambridge Archaeological Journal 5.2:283-289.

- 2000. The pet gazelle of one of the ladies of the Pinudjem family. KMT 11.2:58-61.

- (ed.) 2005. Divine creatures: Animal mummies in ancient Egypt. Cairo/New York: The American University in Cairo Press.

- 2005a. Divine creatures: Animal mummies. In Ikram, S (ed.), Divine creatures: Animal mummies in ancient Egypt, 1-15. Cairo/New York: The American University in Cairo Press.

- 2005b. Manufacturing divinity: The technology of mummification. In Ikram, S (ed.), Divine creatures: Animal mummies in ancient Egypt, 16-43. Cairo/New York: The American University in Cairo Press.

- 2005c. Protecting pets and cleaning crocodiles: The animal mummy project. In Ikram, S (ed.), Divine creatures: Animal mummies in ancient Egypt, 207227. Cairo/New York: The American University in Cairo Press. 
- 2010. Mummification. In Dieleman, J \& Wendrich, W (eds.), UCLA Encyclopedia of Egyptology, Los Angeles.

http://escholarship.org/uc/item/0gn7x3ff. Accessed 17 December 2012.

Ikram, S \& Dodson, A 1998. The mummy in ancient Egypt: Equipping the dead for eternity. London: Thames \& Hudson.

Ikram, S \& Iskander, N 2002. Catalogue Général of the Egyptian Museum: Non-human remains. Cairo: Supreme Council of Antiquities.

Jackowski, C et al 2008. Common and unexpected findings in mummies from ancient Egypt and South America as revealed by CT. RadioGraphics 28:1477-1492.

Kessler, D 1989. Die heiligen Tiere und der König, Teil I: Beiträge zu Organisation, Kult und Theologie der spätzeitlichen Tierfriedhöfe, ÄAT 16. Wiesbaden: Harrassowitz.

- 2003. Tierische Missverständnisse: Grundsätzliches zu Fragen des Tierkultes. In Fitzenreiter, M (ed.), Tierkulte im pharaonischen Ägypten und im Kulturvergleich, IBAES IV, 33-68 Berlin: Humboldt-Universität. http://www2.hu-berlin.de/nilus/net-publications/ibaes4/publikation/ tierkulte.pdf. Accessed 17 December 2012.

Kessler, D \& Nur el-Din, A H 2005. Tuna al-Gebel: Millions of ibises and other animals. In Ikram, S (ed.), Divine creatures: Animal mummies in ancient Egypt, 120-163. Cairo/New York: The American University in Cairo Press.

Kurushima, J D et al 2012. Cats of the pharaohs: genetic comparison of Egyptian cat mummies to their feline contemporaries. Journal of Archaeological Science 39:3217-3223.

Lucas, A \& Harris, J R 1962. Ancient Egyptian materials and industries. London: Edward Arnold.

Lynnerup, N 2009. Methods in mummy research. Anthropologischer Anzeiger 67.4:357-384.

Málek, J 1993. The cat in ancient Egypt. London: British Museum.

McKnight, L M 2010. Imaging applied to animal mummification in ancient Egypt. British Archaeological Reports international series 2175. Oxford: Archaeopress.

Morgan, L et al 2011. Comparison of two falconid mummies from the late period of ancient Egypt using noninvasive techniques. Journal of Raptor Research 45:357-361.

Nicholson, P T 2005. The sacred animal necropolis at North Saqqara: The cults and their catacombs. In Ikram, S (ed.), Divine creatures: Animal mummies in ancient Egypt, 44-71. Cairo / New York: The American University in Cairo Press. 
Partridge, R B 1994. Faces of pharaohs: Royal mummies and coffins from ancient Thebes. London: Rubicon Press.

Pettigrew, T J 1834. History of Egyptian mummies. London: Longman, Rees, Orme, Brown, Green \& Longman.

Ray, J D 2005. An inscribed linen plea from the sacred animal necropolis, North Saqqara. The Journal of Egyptian Archaeology 91:171-179.

Redford, D B 2010. City of the Ram-man: the story of ancient Mendes. Princeton: Princeton University Press.

Schmidt N M et al 2002. Diet of kestrels Falco tinnunculus on grazed coastal meadows. Dansk Ornitologisk Forenings Tidsskrift 96:171-175.

Smelik, K A D \& Hemelrijk, E A 1984. 'Who knows not what monsters demented Egypt worships?' Opinions on Egyptian animal worship in Antiquity as part of the ancient conception of Egypt. In Temporini, H \& Haase, W (eds.), Aufstieg und Niedergang der römischen Welt (ANRW). II Principat, 17,4 Religion, 1852-2000. Berlin / New York: W De Gruyter.

Taylor, J H 2010. Egyptian mummies. London: The British Museum Press.

te Velde, H 1980. A few remarks upon the religious significance of animals in ancient Egypt. Numen 27.1:76-82.

Wade, A D et al 2012. Foodstuff placement in ibis mummies and the role of viscera in embalming. Journal of Archaeological Science 39:1642-1647.

Williams, A R 2009. Animals everlasting. National Geographic 216.5:30-51. 